Entretextos

Entretextos 21(1): jan./jun. 2021

ISSN 1519-5392 UEL

DOI: $10.5433 / 1519-5392.2021 v 21$ n1.p.159

\title{
O açúcar em Rosa: \\ Metáfora, deslizamento de sentidos e condições de pro- dução
}

\author{
Sugar in Rosa: \\ Metaphor, displacement of sense and conditions of production \\ Azúcar en Rosa: \\ Metáfora, deslizamiento de sentidos y condiciones de producción
}

\begin{abstract}
RESUMO: O objetivo deste artigo é analisar os deslizamentos de sentidos possíveis da metáfora "O açúcar é um pozinho branco que dá muito mau gosto ao café, quando não se lho põe", de João Guimarães Rosa, considerando as suas diferentes condições de produção. Assim, busca vislumbrar como essa metáfora esconde dizeres ideológicos, que podem ser desvendados com uma análise minuciosa a partir das condições de produção e os efeitos de sentido presentes e escondidos, o que revela a necessidade de desvelamento, a fim de (re)conhecer seus mecanismos. O nível do acontecimento vem à tona no estudo dessa metáfora, como trecho de duas versões diferentes: a primeira dentro de uma coluna de jornal, em 1954, que passou por alterações e se tornou a segunda, com o prefácio "Aletria e hermenêutica", do livro Tutaméia, de 1967. Para fundamentar a análise, utilizamos o referencial teórico da Análise do Discurso de linha francesa, em especial Michel Pêcheux e Eni Puccinelli Orlandi, assim como alguns historiadores e críticos literários. Logo, verificamos como a historicidade está/se faz presente em uma metáfora de Guimarães Rosa, contribuido para os seus deslizamentos de sentidos, com um diálogo entre estrutura e acontecimento.
\end{abstract}

PALAVRAS-CHAVE: Metáfora. Análise do Discurso. Guimarães Rosa.

ABSTRACT: This article aims to analyze the possible displacement of sense from metaphor "Sugar is a white little powder that gives coffee a very bad taste, when you don't put it on", from João Guimarães Rosa, considering the different conditions of production. Thus, seek to glimpse how metaphor hides ideological sayings, that can be unveiled with a thorough analysis from conditions of production and the sense effects present and hidden, what reveals the need of unveiling, in order to recognize and how its mechanisms. The level of event comes to light in the study of this metaphor, as a part of two different versions: the first inside a newspaper column, in 1954, that went through changes and became the second one, as the preface "Vermicelli and hermeneutics", in the book Tutaméia, in 1967. To substantiate the analysis, we utilized the theoretical reference of French Line of Discourse Analysis, in particular Michel Pêcheux and Eni Puccinelli Orlandi, as well as some historians and literary critics. Then, we verified how historicity is present

\footnotetext{
* Mestra e Doutoranda em Estudos da Linguagem - Universidade Estadual de Londrina.
} 
in a metaphor of Guimarães Rosa, contributing to its displacement of sense, with a dialogue between structure and event.

KEYWORDS: Metaphor. Discourse Analysis. Guimarães Rosa.

RESUMEN: El propósito de este artículo es analizar los deslizamientos de sentidos posibles de la metáfora "El azúcar es un polvito blanco que da mucho mal sabor al café, cuando no se lo pone", de João Guimarães Rosa, considerando sus diferentes condiciones de producción. Así, busca vislumbrar como la metáfora esconde dizeres ideológicos, que pueden ser desvelados con una análisis exhaustivo a partir de las condiciones de producción y los efectos del sentido presentes y ocultos, lo que revela la necesidad de desvelar, a fin de (re)conocer sus mecanismos. El nível del acontecimiento surge en el estudio de esa metáfora, como extracto de dos versiones diferentes: la primera dentro de una columna periodística, en 1954, que pasó por cambios y se convertió en la segunda, em el prefacio "Fideos y hermenêutica", del libro Tutaméia, de 1967. Para la fundación del análisis, usamos el referencial teórico del Análisis del Discurso de linea francesa, en especial Michel Pêcheux y Eni Puccinelli Orlandi, así como algunos historiadores y críticos literarios. Luego, verifcamos como la historicidad está/se hace presente en una metáfora de Guimarães Rosa, contribuyendo para sus deslizamientos de sentidos, con un diálogo entre estructura y acontecimiento.

PALABRAS CLAVE: Metáfora. Análisis del Discurso. Guimarães Rosa.

\section{Introdução}

O conceito de metáfora tem sido muito estudado tanto pela Literatura quanto pelos Estudos da Linguagem, de modo que diversos teóricos a conceituaram de acordo com suas perspectivas. Com vistas nisso, este trabalho utiliza a abordagem da Análise do Discurso de linha francesa e influência pecheutiana, devido às peculiaridades teóricometodológicas e as imensas possibilidades de trabalho, a fim de guiar os olhos do mero leitor, que passa a ser um analista das minúcias que escondem segredos do texto.

Assim, o escritor João Guimarães Rosa chamou a atenção, tanto por trabalhar fortemente com a metáfora quanto por ser um dos maiores escritores da Literatura Brasileira, com suas singularidades e o trato com a sugestão e o silêncio, o que também estimula as investigações da Análise do Discurso. De acordo com Eni Orlandi (2007), cada manifestação do silêncio funciona em suas especificidades, sendo necessário estudá-lo para compreender os processos de funcionamento da linguagem. Logo, o silêncio é contínuo e permite ao sujeito se mover nas significações, percorrer sentidos e formações discursivas diferentes. Pelo caráter de incompletude, é um dos modos de compreender a pluralidade da linguagem, e o sentido se torna visível pelas condições de produção, a história e a exterioridade. 
A fim de nos delimitarmos, optamos pela metáfora "O açúcar é um pozinho branco, que dá muito mau gosto ao café, quando não se lho põe", que é trecho de textos de diferentes condições de produção: uma, dentro de coluna de jornal, sob o título "Risada e meia", em 1954; e a outra, no prefácio "Aletria e hermenêutica", de Tutaméia (Terceiras estórias), de 1967 (ROSA, 1967). Assim, o objetivo deste artigo é vislumbrar os dizeres ideológicos dessa metáfora, que podem ser desvendados com uma análise minuciosa a partir das condições de produção e os diferentes efeitos de sentido presentes e escondidos, revelando a necessidade de desvelamento, para (re)conhecer seus mecanismos.

Então, a metodologia utilizada se baseia em observar o discurso sob a perspectiva materialista, de modo a inserir o sujeito na sociedade e na história, ou seja, contextualizado, o que se justifica pela abordagem da Análise do discurso - doravante AD - da superfície do texto, que deve ir além e se tornar discurso, graças à sua inserção em determinadas condições de produção. Logo, a partir da leitura bibliográfica de teóricos relevantes à pesquisa, como Michel Pêcheux e Eni Puccinelli Orlandi, buscamos partir da ordem do linguístico para chegar ao que é da ordem do histórico, ou seja, tanto as condições de produção quanto o interdiscurso, por meio do já-dito e esquecido, a fim de observar as memórias que intervêm na construção dos efeitos de sentidos da metáfora de Guimarães Rosa. Assim, buscamos compreender a constituição do sujeito e dos sentidos, por meio de uma análise semântico-ideológica.

Para isso, este trabalho primeiramente traça de forma breve alguns conceitos da $A D$ de linha francesa, a fim de basear a posterior análise. Então, atenta-se exclusivamente à metáfora discursiva, de acordo com Pêcheux e Orlandi, e a seguir discorre sobre o escritor Guimarães Rosa, suas peculiaridades e, em especial, os textos de onde retiramos a metáfora aqui analisada. Logo, analisamos a metáfora "O açúcar é um pozinho branco, que dá muito mau gosto ao café, quando não se lho põe", assim como seus efeitos de sentido e diferentes condições de produção. Por fim, delineamos as considerações obtidas graças à realização deste trabalho.

\section{Fundamentação}

Com o surgimento da disciplina no final dos anos de 1960, a partir dos pensamentos de Michel Pêcheux, a AD nasceu com o terreno fecundo do Estruturalismo, Marxismo 
e Psicanálise, em um espaço da política que buscava meios de abordagem na linguística (MUSSALIM, 2003). Desse modo, Mazière (2007) mostra a proposta de trabalhar, no seio das ciências da linguagem, um programa de tratamento da questão do sentido, ansiando a interdisciplinaridade.

De acordo com Mazière, a AD propõe a construção de interpretações que levem em conta dados de língua e de história, o que necessita da tríplice relação com o sujeito assujeitado, a materialidade das formas (estrutura) e a historicidade (acontecimento). Assim, apesar de a classificação ser um pano inicial essencial e útil, a AD não trata apenas de regras, mas pode analisar o sentido e os efeitos das ocorrências, ou seja, a partir da estrutura linguística, enxergar as condições de produção e históricas. Logo, pode utilizar a estrutura para explicar os diferentes efeitos de sentidos, assim como atestar o modo como esses sentidos foram produzidos e por que dizem o que dizem.

Pêcheux (1990) defende que a relação entre acontecimento e estrutura evidencia que um mesmo acontecimento histórico pode produzir diferentes enunciados que remetem a diferentes acontecimentos discursivos, graças às ideologias predominantes. Para ele, a descrição e a interpretação não podem se separar, pois funcionam concomitantemente, sendo o estruturalismo a tentativa antipositivista de entrecruzamento de linguagem e história. Além disso, a interpretação desestabiliza os sentidos por apresentar as possibilidades de deriva e novas práticas de leitura, e a presença dos não-ditos.

Assim, a AD concebe o discurso como uma manifestação da ideologia, não considerando o sujeito quem decide sobre os sentidos do próprio discurso, não sendo livre para dizer o que quer, mas levado, sem consciência disso, a ocupar um lugar em determinada formação social e enunciar o que é possível a partir do lugar que ocupa. Isso também pode ser chamado de formação discursiva, que são as regularidades sobre uma dispersão de objetos, representada pelo coletivo por meio do trabalho sobre o intradiscurso, porém não pode ser considerada como um bloco fixo e imutável (MAZIÈRE, 2007). Para Pêcheux (1995), cada formação ideológica comporta uma ou várias FDs interligadas, além de ser um "conjunto complexo de atitudes e de representações que não são nem individuais e nem universais". Ainda de acordo com Pêcheux (1975), a identidade é resultado da identificação do sujeito que se inscreve em uma (e não em outra) FD para que suas palavras tenham sentido e, ao mudar para outra FD, as palavras também mudam de sentido. Orlandi (2001), por sua vez, mostra que a FD determina o que pode e deve 
ser dito, pois os sentidos são determinados ideologicamente. Como todo discurso se delineia na relação com outros presentes ou na memória, a FD é a regionalização do interdiscurso, assim como as configurações específicas dos discursos em suas relações. Portanto, a FD é a responsável por delimitar e delinear as possibilidades do dizer, de acordo com a identificação do sujeito, de modo a gerir os efeitos de sentido, que são mutáveis na passagem entre diferentes FDs.

Juntamente com a FI e a FD, as condições de produção determinam o que pode e deve ser dito em determinada ocasião, pensadas por Pêcheux (1975) para designar não somente o meio ambiente natural e institucional do discurso, mas as representações imaginárias da própria identidade dos interlocutores, assim como o referente dos discursos. De acordo com Orlandi (2006), as condições de produção abrangem os sujeitos e a situação, sendo que a situação inclui seu sentido estreito - as circunstâncias da enunciação, o contexto imediato - e o sentido lato - a situação compreende o contexto social, histórico, ideológico, de maneira mais ampla. Pensando nisso, a memória discursiva e o interdiscurso fazem parte das condições de produção, existindo em toda língua uma série de mecanismos de projeção que permitem passar da situação sujeito para a posição sujeito no discurso.

Conforme Mussalim (2003), as condições de produção do discurso mostram que a relação imaginária do sujeito com o próprio discurso é uma manifestação da tentativa ilusória de controle, como visto que o sujeito não é senhor de sua vontade. Logo, o sujeito não tem acesso às reais condições de produção do discurso, graças à inconsciência de ser atravessado. Ou seja, o sujeito não é livre para dizer o que quer, a própria opção do que dizer já é em si determinada pelo lugar que ocupa no interior da FI à qual está submetido, mas as imagens que o sujeito constrói ao enunciar só se constituem no próprio processo discursivo.

Assim, os efeitos de sentido são produzidos pelo conhecimento das condições de produção, que não estão evidentes, mas opacas e escondidas e detêm a ilusão do controle do sujeito sobre o que é dito, representadas pelo contexto social, histórico, ideológico, de maneira mais ampla, e a situação imediata da enunciação. As condições de produção também dissimulam o inconsciente do sujeito, por meio da memória discursiva, graças ao interdiscurso.

Para Orlandi (2001), a memória se relaciona ao próprio interdiscurso, que é o que 
se fala antes, em algum lugar, de modo que a memória discursiva é o saber discursivo que torna possível todo dizer e retorna sobre a forma do pré-construído, sendo o já dito, as experiências passadas, na base do dizível. $A$ autora distingue interdiscurso e intradiscurso, sendo o primeiro o eixo vertical de todos os dizeres já ditos (e esquecidos), assim como o plano do dizível; por outro lado, o eixo horizontal é a formulação do que estamos dizendo naquele momento dado, em condições reais. Assim, todo dizer se encontra na confluência dos dois eixos: memória (constituição) e atualidade (formulação). Graças aos esquecimentos, só uma parte do dizívelé acessível ao sujeito, pois mesmo o que não diz (e muitas vezes desconhece) significa.

Orlandi (2001) explica que sujeito e sentido são incompletos, não se constituem definitivamente, mas funcionam sob o modo do entremeio, da relação, da falta, do movimento. Assim, pode-se perceber o equívoco, que tem no processo polissêmico, na metáfora, o seu ponto de articulação. Além disso, a autora demonstra que sempre há o incompleto, o possível pela outra interpretação, o deslize, a deriva e o trabalho da metáfora. Logo, vemos que o inconsciente do sujeito manifesta, por meio do equívoco, as ideologias e, então, toca a história e constitui a ideologia (ORLANDI, 1996). A mesma autora explica que o equívoco é a condição do significar, pois cria a ilusão da literalidade, ou seja, o único sentido. Em outras palavras, o equívoco é um lugar preeminente na $A D$, sendo inclusive um fato estrutural implicado pela ordem do simbólico, servindo para mostrar a pluralidade dos gestos da leitura, assim como as derivas, de acordo com Orlandi.

Para a $A D$, a metáfora é efeito de sentido próprio da produção de sentidos na linguagem, e um dos dispositivos do percurso metodológico, não meramente transposição de sentidos e desvios. Além, Orlandi (2006) defende que o "efeito metafórico" é questão do funcionamento na relação do discurso com a língua, fazendo com que não se trabalhe apenas com o que as partes significam, mas quais as regras que possibilitam.

Orlandi (2001) explica que a metáfora é constitutiva do processo de produção de sentido e constituição do sujeito, não como desvio, mas transferência e deslizamento. Assim, o processo de produção de sentidos está sujeito ao deslize, com um "outro" possível e ausente que o constitui, escondido entre o não-dito e o já-dito. Isso demonstra o que o interdiscurso significa: a relação do discurso com uma multiplicidade de discursos, ou seja, um conjunto não discernível de discursos que sustentam a possibilidade de discurso e a memória do dizer. 
Assim, para Pêcheux (1990), a metáfora é o fenômeno semântico produzido por uma substituição contextual, a possibilidade de um enunciado se tornar outro, de modo que a metáfora não é desvio, mas transferência constitutiva do sentido. Logo, conceber o efeito metafórico como constitutivo do funcionamento discursivo favorece a concepção da ideologia, e também auxilia na compreensão da historicidade. Segundo Pêcheux (1990), a relação entre acontecinmento e estrutura mostra que um acontecimento histórico pode gerar vários enunciados que remetem a diferentes acontecimentos discursivos, e a interpretação desestabiliza os sentidos por apresentar as possibilidades, novas práticas de leitura e a presença dos não-ditos.

Essas derivas são próprias à metáfora, já que deslizam os sentidos e cujas novas significações variam de acordo com suas relações sociais, uma vez que todo enunciado é intrinsecamente suscetível de se tornar outro diferente de si mesmo, se deslocando discursivamente, ou seja, a metáfora é deslizamento de sentidos. Além disso, a metáfora é vista como a questão final da discursividade como estrutura ou acontecimento, visto que todo discurso marca a possibilidade de uma desestruturação e uma reestruturação das redes e trajetos.

Assim, é uma palavra tomada pela outra, não há sentido sem metáfora (GADET; HAK, 2001), mas se constitui no deslizamento de sentido, isso porque toda constituição de sentido se faz pela transferência, não havendo literalidade ou sentido fixo. Logo, para Orlandi (2001), a metáfora é onde se manifestam ideologia e historicidade - ou seja, no nível do acontecimento -, já que os sentidos atribuídos pelos sujeitos no inconsciente se mostram pelo equívoco. Em outros termos, a metáfora está presente quando pensamos na incompletude dos sujeitos e dos sentidos, que não são definitivos, mas funcionam sob o modo do entremeio, da relação, da falta, do movimento. Então, sempre há o incompleto, o possível pela outra interpretação, o deslize, a deriva e o trabalho da metáfora, além da ideia de transferência. Nas palavras de Orlandi (1996, p. 21), "o sentido é sempre uma palavra, uma preposição por outra: os sentidos só existem nas relações de metáfora dos quais certa formação discursiva vem a ser o lugar mais ou menos provisório". Nessa mesma linha, Pêcheux (1990, p. 96) defende que o

[...] efeito metafórico é o fenômeno semântico produzido por uma substituição contextual para lembrar que esse deslizamento de sentido entre $x$ e y é constitutivo do 'sentido 'designado por x e y; esse efeito é característico dos sistemas linguísticos naturais, por oposição aos códigos e às 
línguas artificiais, em que o sentido é fixado de antemão.

Assim, a metáfora é efeito de sentido por meio da posição do sujeito (social, cultural, histórico), ou seja, a identificação com certa FD dentro de determinadas condições de produção, assim como a relação com ideologia, memória discursiva e interdiscurso. Então, as transferências e deslocamentos do efeito metafórico mostram o jogo de efeitos de sentidos possíveis, permitindo que um enunciado seja suscetível de tornar-se outro. De acordo com o Pêcheux, a memória discursiva orienta a produção dos sentidos, se evidenciando no efeito metafórico, produzindo uma rede metafórica da incompletude e da contradição. Logo, os processos metafóricos estão presentes em todo o processo de produção de sentidos, e então

[...] o sentido é sempre uma palavra, uma expressão ou uma proposição por uma outra palavra, uma outra expressão ou proposição; esse relacionamento, essa superposição, essa transferência (meta-phora), pela qual elementos significantes passam a se confrontar, de modo que se "revestem de um sentido" não poderia ser predeterminado por propriedades da língua, pois isso seria admitir que os elementos já estão dotados de sentido, que têm primeiramente sentido ou sentidos, antes de ter um sentido. De fato, o sentido existe exclusivamente nas relações de metáfora (realizadas em efeitos de substituição, paráfrases, sinônimos), das quais uma formação discursiva vem a ser historicamente o lugar mais ou menos provisório (PÊCHEUX, 1988, p. 263).

Em conformidade com Pêcheux (1975), a metáfora é concebida como processo sócio-histórico e fundamento da "apresentação" de objetos para sujeitos, não se limitando a uma forma de falar baseada em um sentido primeiro e não-metafórico, segundo o qual o objeto seria um dado natural. Circulando entre as diferentes FDs, Orlandi (1993) mostra que a metáfora carrega a "ilusão da unidade do sentido", de modo que o sentido deixa de ser único, mas se faz opaco. Orlandi (1996) defende que a metáfora também é atravessada pela história, produz os efeitos na relação entre sujeito e sentidos. Logo, a metáfora está no nível do acontecimento e da enunciação, com base na constituição do sujeito. Ao deslizar o sentido, a metáfora retorna com a inscrição da alteridade e assim constitui a identidade do sujeito.

Assim, a concepção da AD de linha francesa caracteriza a metáfora sempre no nível do acontecimento e, portanto, da história. Além disso, apesar de o sujeito ter a 
ilusão do sentido único, os discursos estão à deriva e não fechados em si, mas capazes de adquirir diversas significações presentes no interdiscurso e inacessíveis por completo. Logo, a significação de uma metáfora pode variar conforme a inserção em certas FDs, variando de sujeito para sujeito, e com a identificação com alguma FI, que determina a ideologia que 0 atravessa, assim como as condições de produção às quais pertence.

Utilizando diversas metáforas em toda a sua obra, João Guimarães Rosa (19081967) é um autor notável, trazendo e amplificando o legado regionalista e tratando o sertão como metáfora da literatura e do ser humano. Guimarães Rosa buscava a junção da linguagem e da vida como se fossem uma coisa só, o que se evidencia nas suas produções, com um léxico único, e a linguagem como verdadeira matéria dos seus textos, por isso a importância para os Estudos da Linguagem. Para Brait (1982), a linguagem de Guimarães Rosa era contra a tirania da gramática, com novos significados a partir da experiência estética universal, com a fusão entre real e mágico, de forma a expressar os processos mentais e verbais inerentes ao contexto fornecedor de matéria-prima. 0 escritor tinha um modo único de enfrentar a palavra, afirmando a gramática ser inventada pelos "inimigos da poesia", e assim abalou padrões, sendo considerado pelos críticos um divisor de águas da ficção brasileira.

De acordo com Candido (1972), Guimarães Rosa tinha fórmulas pessoais, desromantizando o romance, transitando entre prosa e poesia, enredo e sugestão, coerência e confusão temporal. A fusão entre lírica e narrativa revitalizou os recursos da expressão poética, imortaliando os valores espirituais, humanos e culturais de um povo em transição. Já para Bosi (1994), Guimarães Rosa dialogava entre sagrado e demoníaco, com animais e paisagens como agentes participativos, e as concretizações da sensibilidade, consciência pré-lógica e rica cultura popular. A religiosidade do autor é ampla em sua obra, com uma mitologia própria e um universo criado a partir das palavras.

Galvão (2006) enxerga Guimarães Rosa como o rapso do do sertão, que ocupa um lugar privilegiado na literatura brasileira, escolhendo o interior mineiro para evidenciar a fala sertaneja e a erudição de poliglota, com arcaísmos e regionalismos, neologismos e adaptação de estrangeirismos. 0 tratamento riquíssimo à alteridade, à oposição e até mesmo à antítese, de acordo com Galvão, demonstra as ambiguidades entre diferença e semelhança entre gênero, classe e origem nacional. A matéria do sertão para Rosa é fecundada pelos achados formais, sobretudo linguísticos, sendo que o regionalismo está 
do lado da reação espiritualista, fazendo com que a obra rosiana incorpore e supere conquistas precedentes.

As galas da linguagem de Guimarães Rosa se basearam em enciclopédias, travalínguas, charadas, parlendas e jogos verbais, já que o autor era um colecionador de dicionários. A correspondência com os tradutores também demonstra a tamanha preocupação do escritor com a linguagem. Além disso, há fragmentos e cartas de familiares que evidenciam as linhas mestras da criação verbal de Guimarães Rosa, que brincava com a morfologia e os deslocamentos de sentidos.

Logo, a constituição do sujeito-autor dependeu dessas diversas FDs com as quais se identificou e nas quais se inseriu, interpelando-se pela ideologia e transpondo isso ao nível de seu discurso. Além disso, as condições de produção também puderam evidenciarse, na medida em que são históricas e se relacionam diretamente com o interdiscurso, ou seja, os dizeres já-ditos e esquecidos, mas que deixam vestígios no discurso.

A metáfora selecionada para a análise deste artigo foi publicada como trecho de duas versões do texto que viria a ser o prefácio "Aletria e hermenêutica", da última obra de Rosa publicada em vida - Tutaméia (Terceiras estórias) (1967) - e, portanto, em condições de produção diversas. Anteriormente, o texto foi publicado sob o título "Risada e meia", durante o período de colunista de Rosa no jornal Correio da manhã, do Rio de Janeiro, no dia 4 de maio de 1954. Porém, esse primeiro texto sofreu diversas alterações e acréscimo - como a adição de mais metáforas -, preciosismo característico de Guimarães Rosa. Por outro lado, manteve algumas, mas agora com outras condições de produção - na historicidade, 13 anos de diferença, e no meio de publicação: de jornal a prefácio de livro.

Tanto o texto de 1954 quanto o de 1967 trazem uma série de metáforas que poderiam também ser analisadas, porém optamos pela do açúcar, por estar presente nas duas versões, possibilitando a comparação entre as diferentes condições de produção. Além do mais, os deslizamentos de sentidos evidenciados são muito ricos, como veremos mais profundamente na parte da análise, o que evidencia muitas das características da escrita de Rosa, como a metafísica, a sugestão, a ausência e os contrastes. 


\section{Análise}

A metáfora escolhida para a análise deste artigo é um fragmento presente em duas versões de um texto de Guimarães Rosa, porém em diferentes condições de produção. A partir da sequência "O açúcar é um pozinho branco, que dá muito mau gosto ao café, quando não se lho põe", buscamos encontrar a metáfora na estrutura canônica, em que $x$ é $y$, e com uma coisa em termos da outra. Assim, chegamos a "O açúcar é a ausência do amargo", em que o primeiro é um conceito concreto usado para explicar a ideia abstrata subsequente. Pelo viés da $A D$, é possível também mostrar como os sentidos deslizam, ou seja, há transferência de sentidos, dependendo da leitura e da compreensão de certos termos discursivos, como o interdiscurso e as condições de produção, que explicam a forma como a mesma estrutura pode estar relacionada a diferentes acontecimentos discursivos. Em outras palavras, cabe à $A D$ a descrição e a interpretação de como as palavras podem significar diferente.

A metáfora define o açúcar por meio da exclusão e da negação, graças às palavras "mau" e "não", sendo o café ruim, amargo, com a ausência da doçura. Portanto, o açúcar é o responsável por deixá-lo doce. Assim, quando o doce não está, percebemos o quanto as coisas são ruins e, portanto, precisamos da poesia, ou seja, das palavras agradáveis para não encararmos a vida real e crua, amarga como o café sem açúcar.

A estrutura "açúcar" logo traz à memória discursiva as sobremesas e os doces, servindo inclusive como um agradável calmante emocional, por liberar o hormônio da serotonina e, assim, regular o humor, proporcionando também disposição e energia. Por outro lado, não podemos esquecer as restrições de açúcar, especialmente nas dietas de doentes crônicos ou com propensão e histórico familiar, especialmente diabéticos, hipertensos e cardiopatas, pois o açúcar, apesar da doçura, também pode provocar aumento da gordura e, assim, a desregulação da insulina e o entupimento dos vasos sanguíneos. Logo, por mais doce que seja, é necessário o consumo de açúcar de maneira moderada, a fim de evitar enfermidades e até mesmo o sobrepeso.

Pensando ainda na mesma estrutura, a memória discursiva também pode ativar os efeitos de sentido de algo ou alguém que é meigo ou suave, com uma doçura no sentido conotativo, ou seja, que cause uma boa impressão, pela bondade, gentileza ou carinho. Portanto, a ausência do açúcar poderia mostrar o desagrado ao paladar, ou então uma restrição na dieta, e até mesmo a falta de uma coisa, pessoa, animal ou 
situação afetuosa, evidenciando aqui inclusive a temática da morte. Desse modo, a mesma estrutura pode evocar diferentes efeitos de sentido, dependendo das condições de produção e dos acontecimentos discursivos.

Por sua vez, a estrutura "café" também evoca vários efeitos de sentidos, como as pequenas refeições, ou então desjejum, comuns nos períodos da manhã ou da tarde, acompanhadas por singelas porções de comidas, em geral pães, bolos, biscoitos, dentre outros, e pode-se servir ou não o café propriamente dito. Esse líquido é feito a partir do grão do café torrado, moído e cujo processo pode incluir diferentes tipos de preparo, como o expresso, o coado, o americano, com leite, creme, chocolate, chantilly e até mesmo especiarias. Portanto, não existe uma única forma de se fazer ou se tomar café, e cada detalhe pode influenciar no sabor, podendo ser amargo, doce, frutado e inclusive alcoólico.

Os benefícios conhecidos do café são muitos, dentre eles a sensação de bem-estar e diminuição da dor de cabeça e da fadiga, graças à presença da cafeína, que também proporciona um maior estado de alerta e atenção prolongada, capaz de ajudar a manter acordado em situações exaustivas, como trabalho, estudo e até mesmo festas. Por outro lado, o café também pode trazer certos prejuízos para a saúde de quem toma, principalmente se a pessoa já tempropensão, como o aumento do refluxo gástrico, gastrite e outros problemas gástricos, assim como quadros de ansiedade e alterações do sono, causando insônia, assim como taquicardia e tremores. Logo, a mesma estrutura pode adquirir diferentes efeitos de sentido, dependendo das condições de produção e, também, da memória discursiva de cada sujeito.

Observando a relação entre o café e o açúcar, percebemos o contraste e até mesmo a oposição entre as cores, já que o primeiro, se puro, tende a ser escuro, quase preto, enquanto o segundo, na maior parte dos casos, é branco. Assim, na metáfora, a ausência da cor branca dentro da cor preta traria um gosto ruim, como se opusessem luz e escuridão, e a falta do açúcar marcaria também a falta de prazer, ou seja, de coisas boas que tiram o amargor das situações difíceis da vida. Portanto, mais uma vez, a temática da metafísica e da vida vem à tona, escondida pelos não-ditos, mas evidente graças à inserção no interdiscurso e à ativação dos já-ditos na memória discursiva. Além disso, as condições de produção também podem guiar a leitura da metáfora, fazendo com que os sentidos deslizem e mostrem seus diferentes efeitos. 
As condições de produção desta metáfora são duas diferentes, assim como os efeitos de sentido gerados por elas. A primeira versão foi publicada em forma de uma coluna de jornal, enquanto a segunda, dentro do prefácio de um livro. A versão de 1954 ocorreu em um momento político conturbado dentro do contexto brasileiro, com o segundo governo de Getúlio Vargas, que, de acordo com D'Araújo (1992), marcou um período de mudanças e contradições, dentre elas o ferrenho nacionalismo juntamente com o incentivo à imigração. Nas palavras de D’Araújo (1992, p. 9), a

Oposição radical Ihe poderia ser fatal, como foi na conjuntura de 1954. Por aí vem a repressão brutal que ele permitiu contra os comunistas. Logo a ditadura do Estado Novo, para a qual invocava as ameaças do comunismo e do integralismo, bem como do choque sangrento entre os "extremismos". A repressão, nos tempos bravos, não chegava, porém, a radicalizar-se. Era amenizada pela própria técnica de cooptação ou silenciamento digno dos adversários. Não impunha conversão, apenas que não estivessem agindo contra.

Portanto, vemos brevemente a respeito das contradições do segundo governo de Vargas, que foi desde 1951 até 1954, ano da publicação da primeira versão do texto de Guimarães Rosa, juntamente com a metáfora aqui analisada. Quanto à metáfora em questão, a ausência do açúcar que deixa o café amargo pode fazer referência a essas condições de produção, dentre elas a negação do comunismo a qualquer custo, o que continuaremos vendo na segunda versão da metáfora. Porém, aqui as ausências e as faltas se mostram completamente evidentes, já que o governo buscava o afastamento do comunismo e do integralismo, como na citação de D'Araújo (1992), assim como o silenciamento dos adversários que agissem contra a ideologia dominante.

Como sabemos que os paladares de cada pessoa são diferentes entre si, existe quem goste do amargo, ou seja, café sem açúcar, o que, na perspectiva da metáfora, é um gosto ruim. Da mesma forma, podem existir indivíduos que aceitem essas faltas e negações, pois Ihes faz sentido, enquanto para outros é intragável.

Por outro lado, a segunda versão, de 1967, traz um contexto diferente, pois a Ditadura Militar já tinha sido instaurada e estava em pleno auge, de modo que a crise política e social em que se encontrava o país, com base na qual o regime buscava uma ampla adesão da sociedade, com a finalidade de um novo ideário de democracia. Assim, havia os silenciamentos das ideias que se afastassem do desejado pelos militares, por meio da opressão e da falta de liberdade, sempre de modo totalitário e autoritário. 
Rezende (2013) mostra que foram muitas as estratégias de controle político e social, dentre elas promessas, demonstrações de eficiência, propagandas, atos antissociais e crimes, como torturas e assassinatos. Assim, somos levados mais uma vez à metáfora, que trata da ausência do açúcar que traz mau gosto ao café e, portanto, a falta dos desaparecidos e mortos políticos, por discordarem do governo vigente. Em outras palavras, os deslizamentos de sentidos em torno da metáfora mostram que os desaparecidos e mortos por motivos políticos podem ser comparados ao açúcar ausente, que torna o café, ou seja, a vida mais difícil de suportar e com um gosto ruim.

Mais uma vez, dentro das condições de produção dessa metáfora, a censura da Ditadura Militar estava caminhando para a iminência do Ato Institucional $5^{1}$, havia o gosto amargo de não poder dizer o que deseja, e então um silenciamento e a crítica à interdição da palavra. Portanto, enquanto as boas palavras são doces, o silêncio tem um gosto ruim, e vemos, como em Orlandi (2007), que qualquer coisa acaba servindo para significar, mostrando que a força do significante aparece em cheio, pondo tudo em causa e em pauta. Assim, a resistência sempre aparece onde há censura, e então não há censura completamente eficaz, já que os sentidos escapam e migram.

Pensando no silêncio e na ausência, mais uma vez a questão da morte vem à tona, já que as condições de produção assim revelam. De acordo com as palavras de Orlandi (1989, p. 39),

[...] a concepção de silêncio não se esgota nos limites da distinção dito/não dito. Mesmo porque o silêncio não tem de ser referido necessariamente ao dizer para significar. Ou seja, o silêncio significa, ele não fala. A matéria significativa do silêncio é diferente daquela da linguagem verbal, e remeter o silêncio à linguagem verbal é modificar sua matéria significante, o que não é indiferente ao processo significativo.

Portanto, por mais que houvesse o silenciamento, por meio da censura, ainda se buscavam modos de significar e dar sentido às palavras e aos silêncios. Desse modo, a metáfora desliza seus sentidos e mostra que na vida, mesmo com situações amargas e ruins ao paladar, ainda podemos ter momentos bons e doces, como o açúcar, e a lembrança do seu gosto é uma forma de resistência do silenciado.

\footnotetext{
${ }^{1}$ De acordo com Rezende (2013), o Ato Institucional 5, em vigor a partir de 1968, significava a implantação do estado de terror, a fim de continuar e aprimorar a ordem institucional, passando o poder ao Executivo para intervir em todas as esferas da sociedade e institucionalizando a tortura e outras formas de repressão.
} 


\section{Conclusão}

Longe de serem finais, as considerações deste artigo apontam para o futuro e suas imensas possibilidades de desdobramentos, estudos e perspectivas. Graças à observação de uma metáfora de Guimarães Rosa sob olhares da Análise do Discurso de linha francesa, pudemos perceber que a pesquisa e a análise não se findam por completo, e as visões podem revelar novidades com o passar do tempo, ou seja, as condições de produção da leitura.

Tomando a metáfora como discurso, vimos que diversos efeitos de sentidos podem ser captados graças às formações discursivas, às condições de produção e à interpelação do sujeito pela ideologia, não podendo se dissociar delas na busca pelos sentidos. Assim, cada sujeito compreende os efeitos de sentidos de formas diferentes, já que dependem de várias condições de produção, de modo que o discurso aparece como acontecimento, e não somente estrutura.

Para isso, o respaldo da AD francesa mostrou-se como a melhor base teórica, já que utiliza o diálogo entre conceitos como formações discursivas, condições de produção, sujeito, ideologia e interdiscurso para explicar o processo de captação e apreensão dos diferentes efeitos de sentido possíveis. Além disso, a perspectiva abre margem para diferentes abordagens do texto, dentre eles o literário, que apresenta em sua essência um discurso aberto, cheio de possibilidades de interpretações, o que instigou o desenvolvimento desta pesquisa, buscando minúcias e segredos escondidos nas metáforas de um texto de Guimarães Rosa, por meio de uma análise semântico-ideológica.

Ao decorrer da leitura, a metáfora esconde/revela seus sentidos graças às condições de produção do sujeito-autor, em um contexto da Ditadura Militar no Brasil, com o silenciamento e a censura. Isso cria uma atmosfera em torno do mistério, do desconhecido e do vazio. Por outro lado, também foi publicada anteriormente, em 1954, como parte de uma coluna de jornal. Assim, percebemos a forma como a historicidade, ou seja, as condições de produção contribuem para a constituição de outros efeitos de sentido, já que criam diferentes acontecimentos discursivos a partir de uma mesma estrutura.

Segundo Orlandi (1992), toda palavra atesta o interdiscurso ou o silêncio, cujos contornos instáveis cabe à AD delimitar, nas bordas da interpretação. Pensando inclusive na sintaxe da metáfora, que adquire um ar de ensino e explicação, podemos perceber 
alguns efeitos de sentidos nos vazios e não-ditos. Para desvendá-los, precisamos recorrer aos já-ditos, que auxiliam no processo de apreensão dos diferentes efeitos de sentidos, que vagam pelos silêncios. Desse modo, o próprio silêncio apareceu como constituinte da pluralidade da linguagem, limitando o sentido pelas condições de produção.

Por isso, os limites da metáfora não se esgotam, e seriam necessários vários anos e infinitas leituras para apreendermos cada vez mais efeitos de sentidos, com outros jáditos, o que abre a viabilidade de muitos outros estudos dentro da AD. Porém, por agora, nos contentamos com uma possibilidade de interpretação, mostrando o movimento do discurso como efeito de sentidos, sempre dentro de determinadas condições de produção e delimitado por certas formações discursivas. Além disso, o autor-sujeito é parte do processo de construção de sentido, constrangendo-se e relacionando-se com a formação ideológica com a qual se identifica, sendo constituído em suas relações com a exterioridade e, logo, com o acontecimento do discurso.

Por fim, a $A D$, enquanto dispositivo de interpretação, nos revelou que a leitura deve ir além da estrutura e da materialidade textual, o que abre possibilidades para inúmeras pesquisas futuras. A metáfora do açúcar é tão rica em detalhes e segredos, ainda tem muito a nos revelar, assim como toda a obra de Guimarães Rosa, que até hoje instiga pesquisadores e amantes da Literatura Brasileira.

\section{Referências}

BOSI, Alfredo. História concisa da literatura brasileira. 33. ed. São Paulo: Cultrix, 1994.

BRAIT, Beth. Literatura comparada - Guimarães Rosa: seleção de textos, notas, estudos biográfico, histórico e crítico e exercícios. São Paulo: Abril Educação, 1982.

CANDIDO, Antonio. A literatura e a formação do homem. Ciência e Cultura, Campinas, v. 24, n. 9, set. 1972.

D'ARAÚJO, Maria Celina. O segundo governo Vargas 1951-1954: democracia, partidos e crise política. 2. ed. São Paulo: Ática, 1992.

GADET, Française; HAK, Tony. Por uma análise automática do discurso: introdução ao pensamento de M. Pêcheux. Campinas: Editora da Unicamp, 2001.

GALVÃO, Walnice Nogueira. Rapsodo do sertão: da lexicogênese à mitopoese. Cadernos de Literatura Brasileira, São Paulo, n. 21-22, p. 144-186, dez. 2006. 
MAZIÈRE, Francine. $A$ análise do discurso: história e práticas. Tradução de Marcos Marcionilo. São Paulo: Parábola Editorial, 2007.

MUSSALIM, Fernanda. Análise do discurso. In: MUSSALIM, Fernanda; BENTES, Anna Christina (org.). Introdução à linguística: domínios e fronteiras. 3. ed. São Paulo: Cortez, 2003. v. 2, p. 101-142.

ORLANDI, Eni Puccinelli. Análise de discurso. In: LAGAZZI-RODRIGUES, Suzy; ORLANDI, Eni Puccinelli (org.). Introdução às ciências da linguagem: discurso e textualidade. Campinas, SP: Pontes, 2006.

ORLANDI, Eni Puccinelli. As formas do silêncio: no movimento de sentidos. Campinas: Editora da Unicamp, 1992.

ORLANDI, Eni Puccinelli. As formas do silêncio. Campinas: Editora da Unicamp, 2007. ORLANDI, Eni Puccinelli. Discurso e leitura. São Paulo: Cortez, 1993.

ORLANDI, Eni Puccinelli. Discurso e texto: formulação e circulação dos sentidos. Campinas, SP: Pontes, 2001.

ORLANDI, Eni Puccinelli. Interpretação: autoria, leitura e efeitos do trabalho simbólico. Petrópolis, RJ: Vozes, 1996.

ORLANDI, Eni Puccinelli. Silêncio e implícito (produzindo a monofonia). In: GUIMARÃES, Eduardo (org.). História e sentido na linguagem. Campinas, SP: Pontes, 1989.

PÊCHEUX, Michel. Delimitações, inversões, deslocamentos. Cadernos de Estudos Linguísticos, Campinas, n. 19, p. 7-24, jul./dez. 1990.

PÊCHEUX, Michel. O discurso: estrutura ou acontecimento. Campinas: Pontes, 1995.

PÊCHEUX, Michel. Semântica e discurso: Uma crítica à afirmação do óbvio. Campinas: Editora Pontes, 1988.

PÊCHEUX, Michel. Semântica e discurso: uma crítica à afirmação do óbvio. Campinas: Pontes, 1975.

REZENDE, Maria José. A ditadura militar no Brasil: repressão e pretensão de legitimidade: 1964-1984. Londrina: Eduel, 2013.

ROSA, João Guimarães. Tutaméia (terceiras estórias). Rio de Janeiro: Nova Fronteira, 1967. 
Romero, S. Y. W.

Submetido em: 07 out. 2020. Aceito em: 12 fev. 2021. 